This article was downloaded by: [Marc Hooghe]

On: 10 April 2012, At: 16:18

Publisher: Routledge

Informa Ltd Registered in England and Wales Registered Number: 1072954 Registered

office: Mortimer House, 37-41 Mortimer Street, London W1T 3J H, UK

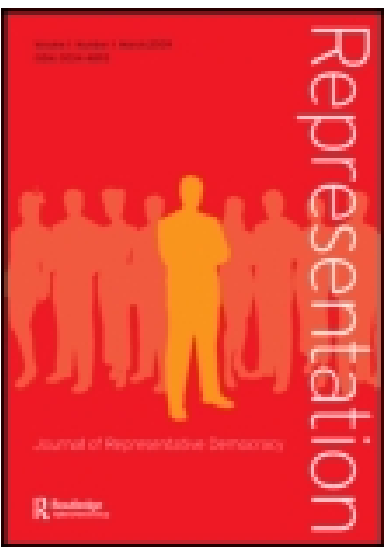

\title{
Representation
}

Publication details, including instructions for authors and subscription information:

http:// www. tandfonline.com/loi/ rrep20

\section{THE POLITICAL CRISIS IN BELGIUM (2007-2011): A FEDERAL SYSTEM WITHOUT FEDERAL LOYALTY}

Marc Hooghe

Available online: 10 Apr 2012

To cite this article: Marc Hooghe (2012): THE POLITICAL CRISIS IN BELGIUM (2007-2011): A FEDERAL SYSTEM WITHOUT FEDERAL LOYALTY, Representation, 48: 1, 131-138

To link to this article: http:// dx.doi.org/ 10.1080/ 00344893.2012.653250

\section{PLEASE SCROLL DOWN FOR ARTICLE}

Full terms and conditions of use: http://www.tandfonline.com/page/terms-andconditions

This article may be used for research, teaching, and private study purposes. Any substantial or systematic reproduction, redistribution, reselling, loan, sub-licensing, systematic supply, or distribution in any form to anyone is expressly forbidden.

The publisher does not give any warranty express or implied or make any representation that the contents will be complete or accurate or up to date. The accuracy of any instructions, formulae, and drug doses should be independently verified with primary sources. The publisher shall not be liable for any loss, actions, claims, proceedings, demand, or costs or damages whatsoever or howsoever caused arising directly or indirectly in connection with or arising out of the use of this material. 


\title{
THE POLITICAL CRISIS IN BELGIUM (2007-2011): A FEDERAL SYSTEM WITHOUT FEDERAL LOYALTY
}

\author{
Marc Hooghe
}

\begin{abstract}
Since 2007, Belgium has been confronted with an ongoing political crisis. As the two language communities in the country grow further apart, it becomes increasingly difficult to form a coalition government with an electoral system that does not provide any incentives for federal loyalty. During the lengthy coalition negotiations a caretaker government had implemented European policies, which might provide a form of economic stability, but does provoke questions about democratic legitimacy and accountability, while questions have also been voiced about the long-term stability of the Belgian political system.
\end{abstract}

\section{Introduction}

Belgium never has been an easy country to govern. In the past, too, the formation of a coalition government usually took quite some time, and since the Second World War, the country has known numerous periods of government instability. There are three major reasons for this lack of governability. The first one is the fact the Belgian electoral system is extremely proportional, and it allows for a multitude of political parties in parliament. In 2003 an electoral threshold of $5 \%$ of the vote was introduced, but this hardly made a difference, as in most electoral districts the 'natural' threshold already was 5\%. In 2003 the explicit goal of government was to dissuade Belgian voters to express a preference for small parties, but this psychological effect was not reached at all (Hooghe 2003). In the 2007 general elections, two smaller parties did not experience any trouble in reaching more than $5 \%$ of the vote, and they gained access to the federal parliament. The Belgian electoral system clearly leads to a multitude of small and larger political parties, which almost inevitably renders it more difficult to form a stable majority in parliament.

A second reason for instability is the increasing fragmentation of the Belgian party system. In the decades immediately following the Second World War the Christian-Democrats were the dominant party, with electoral scores of 35 to $40 \%$. For the Christian-Democrats it was usually quite easy to find a junior coalition partner, either to the left or to the right. Between 1946 and 1999 (a 53-year period), the Christian-Democrats held the position of prime minister for 49 years, and this served as a major source of political stability. The ongoing process of secularisation, however, had as an effect that the Christian-Democrats gradually grew weaker. While in 1965 they held $36 \%$ of all seats in the Chamber, this was down to $19 \%$ in 2003. Increasingly, more parties were needed to form a stable majority, and the Christian- 
Democrats no longer were recognised as the 'natural' leader of the political game, thus ending the implicit rules of the game that led to a political status quo in Belgium.

A third element that is specific for Belgium is the fact that the country no longer has national parties that are active all over the territory of the country. During the 1970s, the three traditional political 'families' (Christian-Democrats, Socialists and Liberals) split up according to linguistic lines, and now there is no formal coordination any more between, for example, the Dutch-speaking and the French-speaking Christian-Democratic Party. While the political parties still show a tendency to join government coalitions on a symmetrical basis (e.g., the Dutch and the French Socialist Party decide together to join a government or not), both parties formulate their own demands, and two separate party conferences will have to decide whether or not to approve of the government coalition. Coordination therefore has become much more complex as basically all decisions have to be taken twice: once on the Dutch side, and once on the French side (Deschouwer 2009).

\section{Stability}

These three elements can help us to explain why forming a coalition government has always been difficult, but gradually has become an almost impossible task. The 1970s and the 1980s typically can be seen as a period of political turmoil, with numerous governments that lost their parliamentary majority before the end of term. These crises resulted in a number of major constitutional reforms, granting more autonomy to the regions of the country. Following this period of turmoil, Belgian politics returned to stability. In a 15-year period (1992-2007) the country only had two prime ministers: Christian-Democrat Jean-Luc Dehaene (1992-99) and Liberal Guy Verhofstadt (1999-2007). The current period of instability, therefore, has to be considered in the perspective that Belgium has just finished a period of almost unprecedented political stability.

During this period of stability, however, linguistic tensions continued to accumulate. The constitutional reforms of the 1970s and 1980s enabled the Flemish and the Walloon region to develop their own political systems, including regional parliaments and governments. Especially the Flemish region gained self-confidence during this period. The regional government developed an innovating policy, and the average income of the Flemish population quickly increased. The Walloon region, on the other hand, remained plagued by economic downturn, especially in the old industrial regions that had been abandoned by the coal and iron industry. This economic division fed the idea that the rich Flemish region was paying for the poor Walloon region. Historically, this is an interesting development, as Flemish nationalism originally was a clear cultural nationalism: in the nineteenth century the Flemish population claimed the right to use its own language, in an era when courts and institutions for higher education were still dominated by French. At the start of the twenty-first century, however, this cultural nationalism increasingly was being replaced by an economic nationalism, as the Flemish nationalists accused the French language group of being 'too lazy' to develop a strong economic take-off.

In order to understand the crisis that kept Belgium without a government for most of 2010 and 2011, we need to go back to the elections of 2003. As was already mentioned, the Christian-Democrats traditionally were the dominant party in Belgian politics, but in 1999 the Liberal Party of Guy Verhofstadt had conquered that position. For the first time in more than four decades, the Christian-Democrats were banned to the opposition and they certainly did not like that position. Their main goal became to regain power in Brussels. The party 
tried to bring new ideas and new politicians to the front, but to no avail: in 2003 Verhofstadt could simply prolong his stay in the 'Wetstraat 16' (the official address of the Prime Minister, comparable to 'Downing Street, $10^{\prime}$ ). The Christian-Democrats faced the spectre of a perennial stay at the margins of power.

But then the Flemish Christian-Democrats decided to join forces with a small radical Flemish-Nationalist party, the 'New Flemish Alliance' (N-VA). The idea was that this would give the Christian-Democrats a more 'Flemish' profile, and this would allow them to reach out to new voters. The new pre-electoral cartel constantly accused the government of Verhofstadt of not paying sufficient attention to the demands of Flemish public opinion. It has to be noted that Verhofstadt indeed provided the opposition with plenty of opportunity for this line of criticism. Already in 1999, there had been some talks about a further devolution of authority in the Belgian constitutional structure. Since these talks did not lead to any clear results, however, Verhofstadt simply decided to shelve the issue, and to concentrate on economic reforms, where his government at least could make some progress. The Flemish ChristianDemocrats and the N-VA fully exploited this weakness, and in 2007 they convincingly won the elections.

During and following the 2007 elections, however, it became increasingly clear that the linguistic segregation of the Belgian party system has some highly negative consequences. The segregation means that the Dutch-speaking parties only compete in the region of Flanders, while the French-speaking parties compete in the Walloon region. Only in the capital Brussels all parties are present, but as Brussels accounts for c. $10 \%$ of the total vote, this does not change all that much. As could be predicted, this segregation provides an incentive for nationalist rhetoric (Horowitz 1985). If a party only has to address Flemish public opinion, it is rather straightforward to promise 'to implement what the Flemish have always asked'. There is hardly a voter in the Flemish region who would object to that. The main problem, however, is that after the election a new coalition government has to be formed, and the nationalist rhetoric has to be abandoned in favour of reaching a compromise. This is especially the case with regard to constitutional matters, where the Belgian constitution rules that the constitution can only be amended by a two-third majority in parliament, with a simple majority in every language group. This means that, unless a majority of Flemish deputies, and a majority of Walloon deputies agrees, nothing can change in the Belgian constitutional framework.

\section{Border Issues}

Somewhat ironically, following the 2007 elections the negotiations to form a new government centred on the boundaries of an electoral district. This discussion, however, had a huge symbolic importance, for both sides. As was already mentioned, only in the bilingual area of Brussels, both Dutch and French political parties compete. Most of the Flemish political parties, however, stated that this electoral district should be limited to the city of Brussels proper. The French political parties, on the other hand, claimed that this electoral district, known as 'Brussels-Halle-Vilvoorde', should extend well into the predominantly Flemish suburbs of Brussels. Symbolically, this is important because it conveys the message that the bilingual area of Brussels extends in a vast region of almost 40 kilometres beyond Brussels (and in a small country like Belgium, that is a large area). The message would be that in this area, both Dutch and French are legitimate languages to be used. The Flemish parties, however, are afraid that this would mean that the bilingual Brussels agglomeration would continue to expand, devouring the territory of the Flemish region where only Dutch serves as an 
official language. To understand this fear, we have to go way back in history: in the fourteenth century Brussels was still a Dutch-speaking town, but the higher cultural and political status of French has meant that French is now the dominant language in Brussels. In extremist Flemish Nationalist groups, the idea is that one should take care to avoid that further 'Flemish territory is lost to the French language group' (Hooghe and Deschouwer 2011).

During the 2007 electoral campaign, Flemish Christian-Democrats and the N-VA had promised their voters that the electoral district of Brussels-Halle-Vilvoorde would be split in a small bilingual Brussels district, and a larger but strictly Dutch district of Halle-Vilvoorde. For the French political parties, on the other hand, this proposal was unacceptable. For them it meant that the French-speaking inhabitants of the predominantly Dutch municipalities in the Halle-Vilvoorde region would lose most of their political rights. The Flemish political parties subsequently argued that they would simply have to vote on the issue, and use the Dutch-speaking majority in parliament. Yves Leterme, the leader of the Flemish ChristianDemocrats, famously stated that all it took was 'five minutes of political courage' to solve this highly salient boundary issue. This fierce nationalist rhetoric did pay off, and ChristianDemocrats and Nationalists won the 2007 elections. An inherent problem in the Belgian political system, however, is that while election campaigns are being fought in every language group separately, forming a workable coalition government requires involvement from both language groups. Theoretically, it would be possible to form a majority with only the Flemish parties (who currently control 88 of the 150 seats in the Chamber), but such a unilateral step would be considered as totally lacking legitimacy. In practice, coalition talks in Belgium are always aimed at reaching more or less a majority within every language group. Lengthy negotiations therefore ensued on the question how to solve the dispute on the boundaries of this electoral district. During this time, the previous Verhofstadt government continued to function, and only in March 2008, the new prime minister Yves Leterme (Flemish Christian-Democrat) was able to assume office. As there was still no deal on constitutional reform, the issue was referred to a special commission. Leterme continued as prime minister until December 2008, when he had to resign over allegations about misconduct during the 2008 financial crisis. A senior statesman of the Flemish Christian-Democrats, Mr Herman Van Rompuy, subsequently took over, and all in all, 2009 was a remarkable stable year for Belgian politics. In November 2009, however, Van Rompuy was elected to be the first permanent president of the European Council, and this meant that Leterme, for the second time, could become prime minister. Again, however, this was not a real success, as in April 2010, the disagreement among the coalition partners about the borders of the Brussel-Halle-Vilvoorde district led to the fall of the government: new general elections were called for June 2010.

\section{The Nationalist Vote}

The June 2010 general elections, therefore, promised to be very unpredictable, as the Belgian population clearly was fed up with the consequences of three years of political crisis and stalemate. Within the French language group, not all that much changed: the Parti Socialiste gained from 30 to $38 \%$ of the vote, and the party clearly confirmed itself as the 'natural leader' of the French-speaking part of Belgium. On the Flemish side, on the other hand, voters switched massively to the Flemish nationalist party N-VA, that obtained $28 \%$ of the vote. Electoral research later on showed that this strong electoral appeal of the party had different causes (Deschouwer et al. 2010). First of all the N-VA attracts voters with a clear nationalist ideology. But beyond this traditional electorate, the party also succeeded in attracting 
disgruntled voters, who were simply fed up with the ongoing political crisis, and who wanted a 'quick solution' to all the problems. The irony, of course, is that these voters actually got the opposite of what they asked for. The N-VA leader, Bart De Wever ( $\left.{ }^{\circ} 1970\right)$ also is considered as a very good and appealing debater, who is highly successful in launching populist rhetoric, and the wide media exposure of De Wever also clearly helped to ensure the electoral success of his party.

Immediately following the June 2010 elections, there was a quite optimistic mood about the prospect of forming a government. Both winners of the elections (N-VA on the Dutch side, PS on the French side) expressed a strong willingness to form a coalition government, and to make an end to the political turmoil of the pre-election period. At some point it even seemed that there was a good personal chemistry between the two protagonists, Bart De Wever (N-VA) and Elio Di Rupo (PS), despite the fact that they are completely opposite figures with regard to personality and style. Already by September 2010, however, it did became clear that divisions between both parties were almost insurmountable, mainly with regard to the distribution of financial responsibility within the Belgian federation. Most of the taxes in Belgium are collected at the federal level, and subsequently some of the money is redistributed to the regions, according to a complicated formula. The formula takes into account the place of residence of taxpayers (and this benefits the Flemish region, where the average income is higher) and the needs of the region (benefiting the Walloon and Brussels regions where unemployment rates are much higher). The net effect of this redistribution mechanism is that there is a considerable transfer of money from the richer Flemish region to the poorer Walloon region. Especially the N-VA insisted on a new mechanism, limiting the 'needs' provision in the formula. According to the Flemish nationalists, the current formula provides an incentive to the Walloon region to keep unemployment levels high, as this results in increased transfers from the federal level. At one point, N-VA leader De Wever even compared the Walloons to 'welfare junkies, surviving on a Flemish lifeline of financial support'. The French-speaking parties, almost self-evidently, were appalled by this Flemish claim, and they noted that every federal system included an element of financial solidarity between the rich and the poor regions. Insisting on more 'financial responsibility' to them amounts to Flemish arrogance.

By the autumn of 2010 it was quite clear that N-VA and PS would never find a compromise on a new financial mechanism for the Belgian federation. What happened in the next six months, however, was a highly complicated game of political charades. All the other Flemish parties were completely mesmerised by the prospect that N-VA would grow even larger. They feared that if they were considered to be 'too lenient' towards the demands of the Frenchspeaking parties, this would be exploited by the N-VA in opposition, and as a result the other Flemish parties could be swept away in the next elections. So the other Flemish parties insisted that the N-VA, as the major political party in Flanders, had to 'assume its responsibility' and conduct negotiations. At several points, the French-speaking parties explicitly stated: 'We will never be able to reach a deal with the N-VA, can't we just negotiate with the moderate Flemish parties?' Because of these electoral reasons, however, the other parties refused. What followed was a kind of chicken game: for everyone involved it was clear that either the PS or the N-VA would have to put an end to the negotiations. The only question, however, was who would actually make that decision. Both parties wanted to avoid the odium of being held responsible for the political chaos that would arise as a result of the breakdown of negotiations. During this period, King Albert II of the Belgians launched several appeals for 'more responsibility among the political elite', but as the king does not have any real authority, these appeals did not produce any result whatsoever. 
This chicken game lasted until July 2011, when eventually the N-VA clearly stated that it had lost all hope of reaching an agreement with the French-speaking parties. After this dramatic rupture, negotiations resumed with only Christian-Democrats, Socialists and Liberals. The Greens, too, were involved in some of the negotiations, but eventually it became clear that especially the Liberals did not want them in a future government coalition, and so they had to leave the negotiating table. With the departure of the extreme Nationalists, it became much easier to reach an agreement. Rather quickly, the negotiating parties reached a deal on splitting up the electoral district of Brussels-Halle-Vilvoorde. The parties also succeeded in making a deal about the financial mechanism: the transfers to the poor regions indeed would be limited, but with a very long transition period that would allow these poor regions to fight unemployment. Once these problems were solved, parties finally could start negotiations about the social and economic policy of the new government to be formed, and this proved to be extremely difficult as especially Socialist and Liberals had completely opposite ideas about these matters. By the end of November 2011, however, external pressure became almost unbearable. The European Commission publicly chastised Belgium for not having a credible budget for the fiscal year 2012, and the Commission threatened to slap heavy fines on Belgium if the budget was not adopted before the end of 2011. Simultaneously, international financial markets lost trust in Belgian government bonds, and the long-term interest rate began to rise sharply. These external developments had more effect than all the internal pressure: two weeks after the European ultimatum a coalition government was formed, and the new government took oath in the hands of King Albert II on Tuesday, 6 December 2011, effectively ending a governmental crisis of 541 days, a new world record for modern democracies. The government, led by the chairman of the Parti Socialiste (Elio

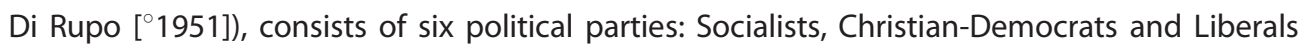
(with for each of these three 'political families' both a Dutch- and a French-speaking party). What is most suprising, however after this long political crisis, is that the Di Rupo government is a very typical consensus government, as Belgium has always known them. The new government wants to transfer some authority to the autonomous regions in the country, while the generous system of early retirements was made stricter. The government budget allows for a budget deficit of $3 \%$ of the GDP in 2012, which is exactly what the European Commission allows.

\section{Causes and Consequences}

Most of the causes for this extremely long process of forming a coalition have already been dealt with. The Belgian electoral system provides political parties with incentives to pay only attention to their own language group during electoral campaigns, and there is no provision at all to ensure federal loyalty. As such, the constitutional structure of Belgium amounts to a worst-case scenario as expressed most strongly in the work of Donald Horowitz (1985). The political elite of Belgium can only be held accountable by its own language group. The fact that the regions have such a high level of autonomy furthermore implies that for aspiring politicians, it is possible to develop most of their career within their own language community. The idea that one has to reach a federal majority with the other language therefore often arises as an afterthought. In 2007, a group of leading academics already put forward the proposal to establish a nationwide electoral circumscription, in an effort to install a sense of federal loyalty. Such a large circumscription would indeed mean that the Dutch language voters could express their support or disapproval for French language politicians, and the other way around. 
Thus far, however, most of the political parties in Belgium have simply refused to debate this proposal. The consequence, most likely, is that in the future the two main language groups in the country will continue to grow apart, and that therefore it will become increasingly difficult to reach political compromises for the Belgian federal system.

For outsiders, the main question often is how Belgium can survive without having a full government for 541 days. The main answer to that question is that the country has a very efficient caretaker government, led by Yves Leterme. While according to the constitution, such a caretaker government can only do 'what is necessary for the country', this notion has continued to expand as the negotiations dragged on. During the autumn of 2011, the Leterme government even went a step further. As the European Union insists on budgetary discipline in the member states, Leterme argued that implementing European demands fell under his scope of authority. This is an interesting development, as the Belgian constitutional provision on the authority of a caretaker government clearly dates from before the era of European integration. In the nineteenth century, lawmakers most likely had military defence and collecting taxes in mind when they wrote this provision. But in the current era of European integration, 'urgent matters' can take on a completely different meaning as Belgium indeed does not have any other choice than to implement European legislation. For the European Union, the fact that Belgium does not have a full government cannot serve as an excuse not to implement budgetary discipline.

On the one hand this can be seen as an indication for the robustness of multilevel government in the European Union. In the past, it would have been impossible to leave a country more than 500 days without a full government. In the current system of multilevel government, the European Union provides an essential safeguard, ensuring, for example, that the budgets of the member states do not completely get out of hand. So in a way, countries now can afford the 'luxury' of remaining without a government for 500 days. It can be observed that this long political crisis did not lead to observable economic damage for the country.

On the other hand, however, questions of democratic legitimacy and representation do arise. The European Union basically forced the Leterme government to implement a strict budgetary police. The Belgian parliament does not play a role in this regard: as the Leterme government was resigning anyway, it no longer could be held accountable by parliament. The basic structures of democratic accountability and decision-making therefore are no longer present in Belgian politics. Even when the Belgian parliament debated the 2012 budget in December 2011, there was not all that much disagreement, as all political parties knew there was no alternative if they wanted to avoid European penalties. Simultaneously, however, everyone knows that the decisions of the European Commission are good advice. Given the fact that the public debt of Belgium amounts to $98 \%$ of its Gross National Product, Belgium indeed has no other option than to limit the annual deficit. It seems that the doctor has prescribed the right medicine for the ailing economy of Belgium. From the point of view of democratic theory, however, it remains highly problematic that the patient itself did not have any say in this decision. Belgium in the end survived this 541-day political crisis, without any permanent damage being done. Two things, however, have become clear. First, it is extremely difficult to keep a federal system fully operational if there is no federal loyalty, let alone political institutions that provide incentives for developing federal loyalty. Second, especially for the smaller member states of the European Union, there is hardly an alternative than to follow the 'recommendations' of the European Commission for budgetary discipline. This loss of sovereignty of the European countries in practice also means that 
national governments are no longer indispensable. Belgium at least has survived 541 days without a government, while all the time remaining within the financial restraints imposed by the European Union. From the point of democratic legitimacy, however, this clearly puts to the front the question of how to increase democratic representation and decisionmaking within the European Union itself.

\section{REFERENCES}

DESCHOUWER, KRIS. 2009. The Politics of Belgium. Basingstoke: Palgrave.

DESCHOUWER, KRIS, PASCAL DELWIT, MARC HOOGHE and StefAAN WALGRAVE (eds). 2010. Les voix du peuple. Brussels: Brussels University Press.

HOOGHE, MARC. 2003. Electoral reform in Belgium: proportionality or mediated politics? Representation 39(4): 264-9.

HOOGHE, MARC and KRIS DESCHOUWER. 2011. Veto players and electoral reform in Belgium. West European Politics 34(3): 626-43.

HOROWITZ, DONALD. 1985. Ethnic Groups in Conflict. Berkeley, CA: University of California Press.

Marc Hooghe is a professor of political science at the University of Leuven (Belgium) and a visiting professor at the universities of Lille (France) and Mannheim (Germany). He holds $\mathrm{PhDs}$ in political science and in sociology. His main research topics are political participation and political trust. He currently holds an advanced research grant of the European Research Council to investigate the occurrence of democratic linkage structures between citizens and the political system. Email: Marc.Hooghe@soc.kuleuven.be 